Soil-geomorphology relationships determine the distribution of the main subalpine grasslands in the Central Pyrenees (NE-Spain)

\title{
Soil-geomorphology relationships determine the distribution of the main subalpine grasslands in the Central Pyrenees (NE, Spain)
}

BADÍA-VILLAS, David ${ }^{1,5^{*}}$, ID ORCID 0000-0002-1006-5030

*E-mail:badia@unizar.es

BUENDIA-GARCÍA, Lucía ${ }^{1,5}$

LONGARES-ALADREN, Luis Alberto ${ }^{2,5}$

MARTÍ-Dalmau , Clara ${ }^{1,5}$

PEÑA-MONNÉ, José Luis ${ }^{2,5}$

GONZÁLEZ-PÉREZ, José Antonio ${ }^{3}$

GÓMEZ-GARCÍA, Daniel ${ }^{4}$

\footnotetext{
${ }^{1}$ Department of Agricultural and Environmental Sciences. Technic School of Agricultural Engineering and Environmental Sciences Universidad de Zaragoza. 22071 Huesca, Spain

${ }^{2}$ Department of Geography and Land Management, University of Zaragoza, 50005 Zaragoza, Spain

${ }^{3}$ IRNAS-CSIC, MOSS Group, Av. de la Reina Mercedes, 10, 41012 Sevilla, Spain

${ }^{4}$ IPE-CSIC, Av. Ntra. Sra. de la Victoria, S/N, 22700 Jaca, Spain

${ }^{5}$ Instituto de Investigación en Ciencias Ambientales de Aragón (IUCA), Universidad de Zaragoza,

Zaragoza 50013, Spain
}

\section{ABSTRACT}

The two most widely extended mountain grasslands in Europe (Nardus-mat grasslands and chalk grasslands) are distributed forming complex patterns. In the Ordesa and Monte Perdido National Park (Central Pyrenees, NE-Spain), they grow as secondary pastures within the treeline ecotone at the subalpine belt. This work aims to show the influence of soil properties on the spatial distribution of these pastures, under a dynamic geomorphology. Soils are sampled under both grasslands, which grow on different cumulative levels: Nardus-mat grasslands in the upper level (L1) and chalk grasslands in the lower level (L2). Soils in L1 have a significantly higher acidity, lower soluble ions and exchangeable calcium content than those in L2, reflecting a more intense leaching process, consistent with a longer period of slope stability. Qualitative differences are detected in the soil organic matter of the soil, using carbon and nitrogen isotopes, lighter in L2 soils than in L1 soils, due to a higher proportion of legumes growing in L2 (chalk grasslands). Soils in L1 and L2 shared many physical properties, such as a fine and homogeneous texture in the whole profile (silty clay or silty clay loam), and high aggregate stability and porosity in the topsoil. In contrast, the soils in L2 are shallower than in L1, which reduces their water-holding capacity. The soil is classified as Orthoeutric Cambisol (Clayic, Humic) in L1 but its rejuvenation, by gully erosion, transforms it into an Hypereutric Leptosol (Loamic, Ochric) in L2 (Typic Haplocryept and Lithic Haplocryept, respectively by Soil Taxonomy system). 
Definitely, the distribution of both grasslands for the studied area is linked to two cumulative levels of different ages, which in turn is strongy related to different soil properties.

Keywords:

Cumulative levels, Nardus-mat grasslands, Soil formation, Soil classification, Late Holocene

\section{Introduction}

Soil formation is a function of parent rock, climate, vegetation, age of the terrain, and topography (Bockheim et al., 2014). Variations in these factors influence soil properties and, as a result of a process of adaptation to the environment, also the plant species distribution changes. The most widely extended grasslands found in the alpine mountains of Europe, and specifically in the Central Pyrenees (Gómez, 2008), seem to be distributed forming an apparently random mosaic under the same altitude, climate, rock, face of the slope, and stocking rate. This is the case for the tussock-forming grass Nardus stricta (hereafter Nardus-mat grassland), which is poor in terms of both species richness $(<20 \mathrm{sps})$ and nutrient quality, and is a grass indicator of acid soils (BraunBlanquet, 1948; Körner, 2003). This grassland grows besides other high diversity grassland (>40 sps) with plants of high fodder value, e.g. Lotus corniculatus, Medicago suffruticosa, Plantago media, Trifolium sp.pl. (hereafter, chalk grasslands) (GarcíaGonzález and Gómez-García, 2014; San Miguel, 2001). In the past, it was common to look for the relationship between plant communities and soil properties (BraunBlanquet, 1948) but there are many gaps in the knowledge of grasslands-soil relationships (Badía et al, 2002a; Fillat et al., 2008). In a general context, a strong influence of geomorphology on plant distribution has been identified (Birkeland, 1999), which in turn has to be connected to some changes in some soil properties. Even smallscale variations in topography modify plant species richness and composition due to changes in soil nutrient distribution (Badía et al., 2008a; Ford et al., 2007; Ehler et al., 2019), mineralization rates (Pintaldi et al., 2016), soil texture (Grab, 1997) or bulk density (Bueno et al., 2013). These microtopographic alterations can be related to bioturbation (Bueno et al., 2013; Ehler et al, 2019,), cryoturbation (Pintaldi et al., 2016) or different erosion processes related to climatic changes or anthropic activities (Świtoniak, 2014). In the subalpine Central Pyrenees, the distribution of those types of grasslands seems to coincide with different cumulative levels, separated by an unevenness of centimetres, related to gully erosion. In fact, these man-made grasslands, 
were reclaimed from the original forest, whose limit (treeline ecotone) on the southern face of the Central Pyrenees could reach up to 2100 masl, to increase the pasture area and to extend the period of time in which pastures were used (Fillat et al., 2008; Montserrat-Martí, 1992; Laborda et al., 2017; Vanniére et al., 2001). These man-made grasses appear to be the origin of the term "alpine" itself in different languages used by farmers in the Alps (Körner, 2003). This human intervention, coinciding or not with any past glacial event in the Pyrenees Massif, may favour the activation of erosive processes, which could have important geomorphological effects in the area (GarcíaRuiz et al., 2014) as well as in other European sites (Henkner et al., 2017). Either from an anthropic or climatic origin, landslide forms are concentrated in the area most affected by deforestation in the Central Pyrenees, at 1800 - 2200 masl (González et al., 1995). Furthermore, according to the same authors, these erosive forms were not found in non-deforested areas located at the same altitude.

Based on these considerations, the aims of this work are as follows: (a) to describe the main Holocene sedimentary records, by means of a geomorphological map, paying special attention to the cumulative levels related to the potential soil formation, (b) to characterize the soil physical and chemical properties and soil formation that determine the distribution of the two most widely spread grasslands in Europe growing on those main cumulative levels and (c) to identify how soil properties leave their mark on soil classification, using the last versions of taxonomic systems (WRB and Soil Taxonomy)

\section{Study Area}

The study site is located in the subalpine belt, approximately 1900 meters above sea level (masl), in the grasslands of La Estiva, in Ordesa and Monte Perdido National Park (PNOMP), in the central sector of the Pyrenees, NE Spain (Fig. 1).

Fig. 1. Location of the zone of study (La Estiva), in the Ordesa and Monte Perdido National Park, Central Pyrenees, north-eastern Spain.

In the nearby Fanlo-Góriz meteorological station, which is located at 2200 masl, the mean annual temperature is $5.1{ }^{\circ} \mathrm{C}$, and the mean annual precipitation is $1698.3 \mathrm{~mm}$ 
(for the period 1982-2017). By season, the average precipitation exhibits a maximum of $568.4 \mathrm{~mm}$ in autumn, a secondary value of $434.1 \mathrm{~mm}$ in spring, and a minimum of $345.8 \mathrm{~mm}$ in winter, quite similar to that in summer (Serrano-Notivoli et al., 2018). The mean annual temperature in summer (June, July and August) is $12.1^{\circ} \mathrm{C}$, and the mean temperature in winter (December, January and February) is $-0.3^{\circ} \mathrm{C}$. The snow period in the study site begins in October and ends in May (Fillat et al, 2008). According to climatic data, we can assume that soils covered by grasslands, not saturated, and without an O-horizon, will have a mean annual temperature lower than $8^{\circ} \mathrm{C}$ (approximately $5^{\circ} \mathrm{C}$ ) and a mean annual summer soil temperature lower than $15^{\circ} \mathrm{C}$ (approximately $12^{\circ} \mathrm{C}$ ), both temperatures measured at a depth of $50 \mathrm{~cm}$ from the soil surface (cryic class). The well-distributed annual rainfall by season, which is higher than evapotranspiration, allows water to move downward through the soil in normal years (udic class). Therefore, the soils at this altitude will have a udic moisture regime and a cryic temperature regime, according to the Soil Taxonomy (ST) classification (SSS, 2014).

From a geological point of view, this sector of the Central Pyrenees, the tallest calcareous massif in Europe, has an alpine mountain landscape resulting mainly from glacial processes and karstification. The most important outcropping materials in the study area are from the Ilerdian, Eocene (Samsó-Escolà and Robador-Moreno, 2018). At the elevation of soil sampling, bioclastic limestones with silex can be found from the middle and lower Ilerdian (Goriz Fm., Gallinera Group). At higher altitudes, other rocks overlap, such as marls, marlstones and grey lutites (Middle Ilerdian, Millaris Fm.) and limestone, marlstone and lutites (Middle and Upper Ilerdian, Metils Fm.). Geomorphologically, the relief is a convex-concave slope linking downslope with the flat surface of the strongly karstified bioclastic limestones, with numerous karrenfields, caves, sinkholes and fissures (Samsó-Escolà and Robador-Moreno, 2018). Although the upper and lower parts of the slope are practically without any sedimentary cover, in the middle and some low sites, there are two cumulative levels (L1 and L2), separated by an erosive escarpment $1.5 \mathrm{~m}$ high, with: 1) at the upper level (L1), the Nardus matgrasslands and 2) at the lower level (L2), a diverse grassland that is mixed with limestone outcrops (hereafter, chalk grassland). The dense tussock-forming grass Nardus stricta (in L1) are poor in terms of nutrient quality (García-González and Gómez-García, 2014) and diversity (species richness<20 sps and Shannon index <2.5) with $N$. stricta, by itself already occupies approximately $60 \%$ of the soil cover. The 
chalk-grasslands (in L2), although with less coverage than Nardus mat-grasslands, are composed by a greater diversity of species ( $>40$ sps and a Shannon index $>4$ ), and with a high fodder value, both grasses (e.g. Festuca nigresecens. Poa spp., Agrostis capillaris) and Fabaceae, e.g. Lotus corniculatus, Medicago suffruticosa and Trifolium montanum, T. pratense and T. repens (Armas et al., 2020). From the phytosociological classification (Benito-Alonso, 2006; Gómez, 2008), the Nardus-mat grasslands belong to the alliance Nardion strictae Br.-Bl. 1926, and the chalk grasslands correspond to Bromion erecti, W. Koch 1926, also known as Potentillo montanae-Brachypodium rupestris Br.-B1. 1967 (San Miguel, 2001). Our preliminary studies showed that the spatial distribution pattern of both grasslands may be linked to some chemical properties of the soil at the root system thickness (Badía et al., 2002a; Badía et al., 2008a; Armas et al., 2020).

\section{Materials and methods}

\subsection{Mapping methods}

A geomorphological map, containing geological information, has been performed to know the characteristics and evolutionary processes of the relief, paying special attention to the extension and morphology of the cumulative levels and the disposition of karst forms. The map was made according to the criteria established by Peña-Monné (1997) using ArcGIS 10.5. The topographic base was obtained from the digital terrain model - MDT02, 2nd Coverage (2015-Present) resolution $2 \mathrm{~m}$, ASCII format (.asc), ETRS89 coordinate system, available at the National Geographic Information Center (CNIG). Geological information has been obtained from two geological maps: sheet 178 at Scale 1:50,000 (Ríos Aragüés et al., 1982) and map scale 1:25,000 (Samsó-Escolà and Robador-Moreno, 2018).

\subsection{Soil sampling and analyses}

Five profiles were dug and sampled in each cumulative level by pairs (side by side): in the L1 covered by Nardus mat-grasslands and in the L2 beneath chalk grasslands. Pedons were described according to FAO guidelines and the morphological 
characteristics of each soil horizon were reported (FAO, 2006). Soil samples were airdried and sieved (mesh size $2 \mathrm{~mm}$ ) to determine the percentage of gravel (>2 mm) and fine earth $(<2 \mathrm{~mm})$. Laboratory analyses were performed on the fine earth fraction (Bitterlich et al., 1999). Soil pH was determined from potentiometric measurements of a 1:2.5 (w/v) suspension of soil and water (current $\mathrm{pH}$ or $\mathrm{pH}-\mathrm{H}_{2} \mathrm{O}$ ) and with $1 \mathrm{~N} \mathrm{KCl}$ (potential $\mathrm{pH}$ or $\mathrm{pH}-\mathrm{KCl}$ ) as well as exchangeable acidity (McLean, 1982). The electrical conductivity (EC) was measured in a 1:5 soil-to-water ratio to determine the amount of soluble ions (Rhoades, 1982a). The total carbonate in the fine earth fraction was measured volumetrically (calcimeter) using a dissolution procedure $(6 \mathrm{~N} \mathrm{HCl})$ that evolves carbonate in the sample to $\mathrm{CO}_{2}$ (Nelson, 1982). The cation exchange capacity (CEC) and exchangeable base cations were determined by ammonium $\left(\mathrm{NH}_{4}{ }^{+}\right)$retention after leaching with a neutral solution of $1 \mathrm{~N} \mathrm{NH}_{4} \mathrm{OAc}$ (Rhoades, 1982b). Soil organic carbon (SOC) was determined by the wet oxidation method (Nelson and Sommers, 1982). From these data, the carbon stocks $\left(\mathrm{kg} \mathrm{SOC} / \mathrm{m}^{2}\right)$ of the soil profiles were calculated for each horizon and profile according to:

$$
\begin{gathered}
{\left[\frac{\mathrm{kg} \mathrm{SOC}}{\mathrm{m}^{2}}\right] \text { profile }=\sum\left[\frac{\mathrm{kgSOC}}{\mathrm{m}^{2}}\right] \text { horizon (1) }} \\
{\left[\frac{\mathrm{kg} \mathrm{SoC}}{\mathrm{m}^{2}}\right] \text { horizon }=\frac{\mathrm{kg} \mathrm{soC}}{100 \mathrm{~kg} \text { fine earth }} \times(1-\text { Stones }) \frac{\mathrm{kg} \text { fine earth }}{\mathrm{kg} \text { soil }} \times \frac{\mathrm{kg} \mathrm{soil}}{\mathrm{m}^{3} \text { soil }} \times \mathrm{m} \text { (2) }}
\end{gathered}
$$

where $\mathrm{m}$ is the thickness (in meters) of each horizon.

Moreover, total $\mathrm{C}$ and $\mathrm{N}$, as well as its bulk isotopic composition, were analyzed by dry combustion in a Flash 2000 elemental micro-analyzer (Thermo Scientific) coupled via a ConFlo IV Universal Continuous Flow Interface (Thermo Scientific) to a Delta V Advantage isotope ratio mass spectrometer (Thermo Scientific, Bremen, Germany) as was previously detailed (Girona-García et al., 2018). The total C measurements correspond to total organic C (TOC) when carbonates are absent. Isotopic ratios are reported as parts per thousand deviations (expressed as $\delta$ values) with respect to the appropriate IAEA standards (VPBD and $\mathrm{V}-\mathrm{Air}$ for $\mathrm{C}$ and $\mathrm{N}$, respectively):

$$
\delta=((\text { Rsample-Rstandard }) / \text { R standard }) \times 1000
$$


where $\mathrm{R}$ is the ${ }^{13} \mathrm{C} /{ }^{12} \mathrm{C}$ or ${ }^{15} \mathrm{~N} /{ }^{14} \mathrm{~N}$ ratio.

The standard deviations of $\delta^{13} \mathrm{C}$ and $\delta^{15} \mathrm{~N}$ were typically less than $\pm 0.05 \%$ and \pm $0.2 \%$, respectively. Variations in soil $\delta^{13} \mathrm{C}$ and $\delta^{15} \mathrm{~N}$ values can be related to changes in the rainfall regimes and in the vegetation or land-uses, i.e. forest, grasslands and agricultural crops and their management (Pardo and Nadelhoffer, 2010).

Fine earth fraction particle size distributions were determined by the discontinuous sedimentation method after removal of organic content with $\mathrm{H}_{2} \mathrm{O}_{2}(30 \%)$ and clay dispersal with 5\% Na-hexametaphosphate (Gee and Bauder, 1986). The coarse sand fraction ranged from 2000-500 $\mu \mathrm{m}$, fine sand from 500-50 $\mu \mathrm{m}$, coarse silt from 50$20 \mu \mathrm{m}$, fine silt from $50-2 \mu \mathrm{m}$ and clay is $<2 \mu \mathrm{m}$ in bulk diameter. Soil samples of each layer were separated in 6 different aggregate sizes $(<0.25,0.25-0.5,0.5-1,1-2,2-4$ and $4-10 \mathrm{~mm}$ ) by manually shaking a nested column of sieves, avoiding aggregate destruction, to obtain fractional samples, which were weighed separately to calculate the mean weight diameter (MWD; Van Bavel, 1949). The stones, rarely present, were removed in the sieve fractions. Soil aggregate stability (SAS) was measured (in aggregates 1-2 $\mathrm{mm}$ in diameter) using the wet-sieving method (Kemper and Koch, 1966). The water content at field capacity, FC (-33 kPa) and at the permanent wilting point, PWP (-1500 kPa) were measured volumetrically using pressure plate extractors (Richards, 1947); its difference gives us the water holding capacity (WHC). Moreover, unaltered soil samples were taken with steel cylinders $(5 \times 5 \times 5 \mathrm{~cm})$ to determine the bulk density of the topsoil. The determination of the real or particle density was established by a pycnometer, which with the bulk density allows us to calculate the porosity (Klute, 1986).

Soils were classified according to the WRB (IUSS, 2015) and Soil Taxonomy (Soil Survey Staff, 2014) systems. Both taxonomies have been endorsed by the International Union of Soil Science (IUSS) as internationally accepted soil classification systems (Hartemink, 2014).

\subsection{Statistical analysis.}


The data were analyzed using the $\mathrm{R}$ version 3.5.1 program. For the comparison of the two soils as a whole, nonparametric tests (Mann-Whitney $U$ test) or robust tests (Yuen t-test) were performed for two independent samples when the data did not meet the assumptions of normality and homoscedasticity necessary for the application of parametric tests. For comparisons between soil horizons (6+4=10 groups), ANOVAs were performed with their corresponding post hoc analysis (Tukey test) when it was possible to use parametric methods. Mainly a robust analysis of variance of a factor (one-way ANOVA, Yuen's t-test) was performed. This analysis is used to compare multiple groups, according to their cropped averages, when the assumptions of normality and homocedasticity are not met due to the presence of outliers. On the contrary, without outliers, Kruskal-Wallis nonparametric tests were performed. Subsequently, Tukey post hoc tests were carried out to determine significant differences $(p=0.05)$ between groups. To identify the relationships between all the measured parameters, the Winsorized robust correlation was performed (Wilcox, 2012). Correlations are indicated in the text for $\alpha=0.01$, unless otherwise specified. To check the relationship between CEC and organic matter and clay, linear regressions between these parameters have been performed. Additionally, principal component analysis (PCA) was carried out using XLSTAT software (v. 2015), based on the correlation matrix and following the standardization of the data, with Varimax rotation and Kaiser normalization

\section{Results and discussion}

\subsection{Geomorphological characterization}

The convex-concave slope is practically without sedimentary cover in the upper and lower sides where limestones outcrop, but in the middle of the slope, there is a cumulative level that extends in the form of fine sediment fans to the flat area (Level L1). This level is affected by incisions of ravines and rills and superficial solifluidal processes, being in many cases a residual level. A subsequent accumulation (Level L2) occupies the bottom of the incisions and the frontal landing, reaching the incisions in many cases with the flat surface of the structural landing, strongly karstified (Fig. 2). On the limestones, the gently rounded morphologies of the karrenfields indicate a subaerial 
genesis beneath the soil, which, once eroded, has exposed them. Some authors identified L1 accumulation, composed of fine sediments, such as loess deposits (GarcíaRuiz and Arbella, 1981), a theory they later abandoned after sediment analysis (GarcíaRuiz and Puigdefábregas, 1982); these resulted from weathering of the marls and limestones, being locally mobilized along the slope (Benito-Alonso, 2006).

Fig. 2. Geomorphological map of La Estiva, PNOMP. The situation of the studied soils, sampled in pairs, in L1 and L2 cumulative levels are indicated with blue and red dots, respectively.

The L1 level forms a deposit of great continuity covering the slopes and valleys of the alpine and subalpine belts, probably all over the Pyrenees, representing a phase of stability that had to be accompanied by the presence of a protective plant cover. In this sense, Nardus stricta mat-grassland forms tussocks with a dense and interwoven stem and root system, which exerts certain resistance against some erosive processes (Löbmann et al, 2020).

In L1, there is neither superficial stoniness nor rock outcrops, but in L2, the surface cover of rock outcrops ranges from common (5-15\%) to many (15-40\%), and coarse surface fragments are common. The cumulative levels (L1 and L2) are separated by an erosive escarpment or unevenness approximately $1.5 \mathrm{~m}$ high with a slope of $55^{\circ}$. Both levels have a gentle inclination $\left(<6^{\circ}\right)$. Although the absolute ages of the upper cumulative level (L1) and its soils are not available, we can note that they are necessarily subsequent to the Last Glacial Maximum since L1 is attached to a glacial till of this phase existing in the area (Fig. 2). Its genesis, due to the fine sediment composition, can be related to the stages of intense alteration of the parent material during a temperate-humid stage within the Holocene, such as the Iron Age Cold Epoch (2.8-2.5 kyrs), whose effects are recognized in large areas of the NE Iberian Peninsula (Peña-Monné, 2018). According to García-Ruiz et al. (2014), the Monte Perdido has suffered intense glacial activity even during recent times: during the Mid Holocene $(5.1 \pm 0.1 \mathrm{kyr})$, the Neoglacial period of the Bronze/Iron Ages and the Dark Age Cold Period (1.4-1.2 kyr), followed by a melting period during the Medieval Climate Anomaly of the $10^{\text {th }}-14^{\text {th }}$ centuries. However, the incision and loss of the cumulative L1 rather than being related to one of those glaciations or melting phases seems to derive from the deforestation carried out by humans to expand the pasture area. Different 
surveys in high mountain environments have revealed humanized past landscapes (Gassiot et al., 2016), at least since the Bronze Age (Laborda et al., 2017; Clemente et al., 2017). Leunda et al. (2020) found a regional opening of the landscape in the Central Pyrenees with an increase in herbaceous cover against forestry, ca. 3000 yrs cal BP onwards, which was related to an increase in the occurrence of human-induced fires. For this period and site (Barranco Pardina, approximately $1790 \mathrm{~m}$ altitude), a level of paleofire preserved in hillside deposits was dated to 3106 yrs cal BP (Laborda et al., 2017). Additionally, in Massif Central, France, at 1450-1700 m altitude, mature beech forest was replaced by Nardus stricta grasslands by regular occurrences of fire events from the Middle Neolithic to the Central Middle Ages as agro-pastoral actions (Bal et al., 2015). In Carpathian mountains, the first signs of human disturbance appeared ca. 4200 cal yr BP, when naturally open areas were used as alpine pastures but the lowering of treeline ecotone by human impact, mainly burning and grazing, was intensified after ca. 2600 cal yr BP (Orbán et al., 2018). Agro-pastoral clearings have also been postulated in the Pyrenees and the Alps with additional data (pollen, archaeology, ecology). On the southern slope of the Pyrenees, the natural upper forest limit reached up to $2100 \mathrm{~m}$ altitude, but it has been lowered to increase the pasture area and to extend the time in which grasslands are used. By palynological methods, it has been demonstrated that the lowering of the treeline was caused by fires set by human activities one thousand years ago (Montserrat-Martí, 1992). Conversely, GonzálezSampériz et al. (2019) highlight that unequivocal human use and the origin of current alpine landscapes are located only a few centuries and not a few millennia ago. The intense deforestation caused by human action in search of pasture expansion has been related to the Medieval Era coinciding with the Medieval Climate Anomaly (MCA) starting from the $12^{\text {th }}-14^{\text {th }}$ centuries (González-Sampériz et al., 2017; Leunda et al., 2017). Additionally, Fillat et al. (1999) conclude that in the $10^{\text {th }}$ and $11^{\text {th }}$ centuries, the disproportionate population density in the Central Pyrenees led to overexploitation of natural resources. Therefore, the Medieval Epoch could be the period when the cumulative level L1, which should have been a majority in the subalpine landscape for a few thousand years, was dismantled by gully erosion. However, we have not found charcoal remains that would suggest forest burnings done by shepherds in that period, unlike that in nearby Ebro Basin (Armas et al., 2018). A phase of some climatic stabilization related to the Little Ice Age (LIA, late 17th century to middle 19th century), colder and more humid, would stabilize the cumulative level L2. This level is 
also being dismantled under the current warm period that has reactivated the incision, exposing the karrenfields (Fig. 3). This type of Holocene evolutionary process bears some resemblance to the accumulation and incision phases described for the slopes of the Ebro Basin and the Iberian Mountain Range (Pérez-Lambán et al., 2014; PeñaMonné, 2018).

Fig. 3. Longitudinal section of the slope in La Estiva, PNOMP, showing L1 and L2 cumulative levels on the geological substrates.

\subsection{Soil properties}

\subsubsection{Morphological properties}

Soil profiles at L2, the lower and thinner cumulative level, host simpler sequences with a reduced set of horizons, such as Ah-R or Ah-Bw-R. However, on L1, an $\mathrm{Ah}-\mathrm{Bw}-\mathrm{C}-\mathrm{R}$ or $\mathrm{Ah}-\mathrm{AB}-\mathrm{Bw}-\mathrm{BC}-\mathrm{C}-(\mathrm{R})$ sequence indeed appears. The R-layer (Eocene limestones) is between 15 and $40 \mathrm{~cm}$ deep in the soils developed on L2 and between 80 and $200 \mathrm{~cm}$ in the soils on L1; therefore, the soils are deep or very deep in L1 and shallow or very shallow in L2. Over time, the cumulative level L1 can be partially preserved, and soil develops but is also largely eroded arising from L2; this is the result of the changing environmental conditions that lead to multiple steady states, as predicted by nonlinear dynamics, which propose nonlinear behaviour in soil landscapes (Huggett, 1988).

Little morphological differentiation within the profiles has been observed, both in L1 and L2; i.e., horizon colour is quite homogeneous. The Ah horizon is slightly darkened by the incorporation of organic matter, which is the most frequent colour: dark yellowish brown (10YR 5/2 dry and 10YR 4/2 wet) in L1, which still clears up slightly more (10YR 6/2 dry and 10YR 4/2 wet) in L2. However, the rest of the horizon colour is quite homogeneous until contact with parental material. The most frequent colour in the $\mathrm{B}$ and $\mathrm{C}$ horizons is pale brown (10YR 7/2, in dry, and 10YR 5/2, in wet). The limit between Ah and the rest of the horizons is clear and smooth but diffuses with depth. The Ah horizons have a granular structure, fine sized, between the dense root system of the grasslands, and it transforms to subangular blocky in the Bw horizons, of medium size and strong development, but that weakens and increases in size at depth to become 
massive ( $\mathrm{C}$ horizons). Calcium carbonate $\left(\mathrm{CaCO}_{3}\right)$ equivalent contents were below the limits of detection in most profiles, neither in L1 nor in L2, and when they rarely appear, they do so in small quantities $(<5 \%)$ and only in the baseline horizon of the profile in contact with limestones $(\mathrm{R})$ or related to lithological discontinuities $(2 \mathrm{C})$; they are lithogenic (geogenic, primary) but not pedogenic (secondary) carbonates. Since the soil profiles were derived from carbonate-rich parent material (limestones, marls, marlstones), the carbonates have had to be leached away, which is already a sign of edaphic evolution. Although carbonates removal is favourable to clay illuviation, morphological evidence of this process, common in humid (Kowalska et al., 2019) and even in semiarid environments (Badía et al., 2013), is not observed in these soils.

\subsubsection{Soil reaction and nutrients}

The profiles studied differ in some chemical properties, specifically acidity $\left(\mathrm{pH} \mathrm{H}_{2} \mathrm{O}\right.$, $\mathrm{pH} \mathrm{KCl}$ and exchangeable acidity), soluble ions (EC), and exchangeable calcium $\left(\mathrm{Ca}^{2+}\right)$, the dominant cation in the exchange complex (Fig. 4), that controls the base saturation (BS).

Fig. 4. Variation in depth of $\mathrm{pH}\left(\mathrm{H}_{2} \mathrm{O}\right), \mathrm{Ca}^{2+}(\mathrm{cmol} / \mathrm{kg})$ and soluble ions $(\mathrm{EC}$, in $\mu \mathrm{S} / \mathrm{cm})$ in soil profiles of L1 and L2 cumulative levels.

The $\mathrm{pH}\left(\mathrm{H}_{2} \mathrm{O}\right)$ is acidic in the whole profile in $\mathrm{L} 1\left(5.6<\mathrm{pH}-\mathrm{H}_{2} \mathrm{O}<6.6\right)$ but neutral in $\mathrm{L} 2$ $\left(6.8<\mathrm{pH}-\mathrm{H}_{2} \mathrm{O}<7.4\right)$. The $\mathrm{pH}(\mathrm{KCl})$ is positively correlated $(\mathrm{p}<0.01)$ with the $\mathrm{pH}\left(\mathrm{H}_{2} \mathrm{O}\right)$. The soil profiles on both L1 and L2 show a consistent $\mathrm{pH}$ increase with depth (Fig. 4), a common fact in leached soils (Bogner et al. 2012). The soluble ions (EC) in L1 are approximately half $(13.5 \mu \mathrm{S} / \mathrm{cm}<\mathrm{EC}<63.4 \mu \mathrm{S} / \mathrm{cm})$ those in $\mathrm{L} 2(40.7 \mu \mathrm{S} / \mathrm{cm}<$ $\mathrm{EC}<112.0 \mu \mathrm{S} / \mathrm{cm})$. The EC shows a contrary behaviour to $\mathrm{pH}$, with maximum values in the topsoil, which is related to the mineralization of the organic matter, a source of soluble nutrients. Also there was a strong negative correlation between $\mathrm{pH}$ and exchangeable acidity $\left(\mathrm{Al}^{3+}\right.$ and $\left.\mathrm{H}^{+}\right)$, which is negligible in the $\mathrm{L} 2$ soil but ranges from 0.4 to $1.7 \mathrm{cmol}_{+} / \mathrm{kg}$ in the $\mathrm{L} 1$ soil, with a maximum in the B horizons (Appendix 1).

Among the available or exchangeable cations, $\mathrm{Ca}^{2+}$ is the most abundant (3/4 of the exchange complex), followed by $\mathrm{Mg}^{2+}$ and $\mathrm{K}^{+}$(Appendix 2). The exchangeable $\mathrm{Ca}^{2+}$ 
content in the $\mathrm{L} 1$ soil is lower $\left(7.0<\mathrm{cmol}_{(+)} \mathrm{kg}^{-1}<11.2\right)$ than that in $\mathrm{L} 2\left(11.8<\mathrm{cmol}_{(+)}\right.$ $\left.\mathrm{kg}^{-1}<17.0\right)$. The calcium content, which does not correlate with the depth in either of the two soils, seems to have a bimodal behaviour, being greater in the surface (coming from the organic matter mineralization) and in the deeper horizons (from calcareous parent material) than that in the intermediate parts of the profiles. In contrast, magnesium and, especially, potassium have their maximum values in the topsoil; potassium content is significantly correlated with the SOC content in both the L1 soil ( $\mathrm{r}$ $=0.95)$ and the L2 soil $(\mathrm{r}=0.88)$, showing that they result from the mineralization of organic matter. The low cattle stocks in La Estiva do not affect the potassium content of either L1 or L2 soil via dung and urine inputs, unlike camping areas (Badía et al., 2008b). For the aforementioned chemical properties, we found significant differences between L1 and L2 soils, taking the set of values of the horizons of each profile (Table 1). Soil $\mathrm{pH}, \mathrm{Ca}^{2+}$ and $\mathrm{BS}$ are parameters usually correlated to each other and, in turn, they are negatively correlated with $\mathrm{Al}^{3+}$ in subalpine soils (Rowley et al., 2020).

\section{Table 1.}

Chemical properties significantly different among L1 and L2 soils, considering the set of horizons by profile (Mean $\pm \mathrm{SD}$ ).

Soil nutrient availability is reflected in the nutritional composition and the fodder value of the grasslands and is higher in the chalk grasslands than in the Nardusmat grasslands (Alonso and García-Olalla, 1997). Nardus-mat grassland, a tussockforming grass widely distributed in Europe (Bitterlich et al., 1999; Korner, 2003; Sebastiá, 2004), has an acidophilic character, as we verified in Aisa, Western Pyrenees (Badía et al., 2002a,b) and the Soaso of Linás de Broto, Central Pyrenees (Otal et al., 2005). Recently, Armas-Herrera et al. (2020) reported that chalk grasslands grow in topsoils (sampling 0-5 and 5-10 cm soil thickness) with greater $\mathrm{pH}\left(\mathrm{pH}-\mathrm{H}_{2} \mathrm{O}\right.$ and $\mathrm{pH}-$ $\mathrm{KCl}$ ), BS and $\mathrm{Ca}^{2+}$ content than that of the Nardus mat-grasslands in the PNOMP. Pintaldi et al. (2016), studying soil properties in a Nardus stricta subalpine hummocky grassland located at $2160 \mathrm{~m}$ altitude (Aosta Valley, North-Western Italian Alps), correlate the abundance of $N$. stricta cover with soil $\mathrm{pH}$ (at 0-10 $\mathrm{cm}$ soil depth), comparing hummocks $(15-30 \mathrm{~cm}$ high) with interhummocks (i.e., the depressions between consecutive hummocks) generated by cryoturbation. Therefore, in hummocks, where $N$. stricta was dominant (with a cover ranging from 78 to 93\%), the soil $\mathrm{pH}$ was 
approximately 5.1, which was significantly lower than that in interhummocks, where the soil $\mathrm{pH}$ was approximately 5.4, with a lower $N$. stricta cover (from 5 to $25 \%$ ). In the interhummocks, the main cover corresponds to forb species, such as Geum montanum, Arnica montana and Trifolium alpinum. Additionally, Armas et al. (2020) found a pH in the Nardus root zone of L1 $(0-10 \mathrm{~cm})$ of approximately 5.2 in the PNOMP. Instead, chalk grasslands growing right next to it but in $\mathrm{L} 2$ had a $\mathrm{pH}$ of 6.3. These $\mathrm{pH}$ values found in La Estiva are not as acidic as those of other alpine mountains, either by lithology (siliceous substrates), climate (high rainfall/evapotranspiration ratio) or geomorphological stability factor over time (Bitterlich et al., 1999; Sebastiá, 2004; Pintaldi et al., 2016). Moreover, in the Pyrenees, a calcareous massif, inputs of carbonates can be added to the soils. As an example, in the central Alps, annual additions of $\mathrm{CaCO}_{3}$ in the dust to the ground, from nearby calcareous rocks, reach up to $1100 \mathrm{~kg} \mathrm{ha}^{-1}$ (Korner, 2003). The $\mathrm{CaCO}_{3}$ contributions (coming from dust, limestones within or on the soil profile or the circulation of water on the calcareous parent material) govern soil biogeochemistry, as buffering of soil $\mathrm{pH}$ and providing a continued supply of $\mathrm{Ca}^{2+}$, even if they are small amounts (Rowley et al, 2020). Exchangeable cations measured in this study, especially $\mathrm{Ca}^{2+}$, show higher levels than in soils developed on siliceous parent material of Sierra de Urbasa (Val and Iñiguez 1981a), the Iberian Range (Hoyos et al. 1983; Badía et al., 2017) or the Alps (Pintaldi et al, 2016).

\subsubsection{Soil organic matter and related properties}

The surface horizon in $\mathrm{L} 1,10 \mathrm{~cm}$ thick, has a similar SOC content to that of the surface horizon in L2 soil (Appendix 3). But taking into account the whole profile, the SOC stock in the whole L1 profile is much greater $\left(16.1 \pm 2.4 \mathrm{~kg} \mathrm{SOC} / \mathrm{m}^{2}\right)$ than that in $\mathrm{L} 2$ $\left(6.1 \pm 2.5 \mathrm{~kg} \mathrm{SOC} / \mathrm{m}^{2}\right)$, because the thickness of the L2 soil is much less than L1. These contents are within the range for soils under grasslands in alpine or subalpine zones (Korner, 2003; Bojko and Kabala, 2017). We had already found significant differences when comparing the same soil thickness $(0-5 \mathrm{~cm}): 91.1 \mathrm{~g} \mathrm{SOC} / \mathrm{kg}$ in $\mathrm{L} 1$ versus $68.7 \mathrm{~g}$ $\mathrm{SOC} / \mathrm{kg}$ in $\mathrm{L} 2$, which is related to variations in organic inputs between both grasslands and the biological activity of their soils (Armas et al., 2020). Additionally, in the Alps Pintaldi et al. (2016) found that the topsoil $(0-10 \mathrm{~cm})$ TOC content of Nardus stricta hummocks $(71 \mathrm{~g} / \mathrm{kg})$ was significantly greater than that in interhummocks $(63 \mathrm{~g} / \mathrm{kg})$.

The SOC and other positively correlated parameters (total N, CEC) reach maximum values in topsoil with very few irregularities in depth (except in some L2 
profiles with an Ab horizon, exhibiting colluviation). The CEC is solely dependent on SOC $(r=0.91)$ but not on clay content $(r=0.08)$, as shown in the following equations:

$\operatorname{CEC}\left(\mathrm{cmol}_{(+)} \mathrm{kg}^{-1}\right)=2.193(\%$ SOC $)+10.667 ; R^{2}=0.828 ; n=29 ; P<0.001$

$\mathrm{CEC}\left(\mathrm{cmol}_{(+)} \mathrm{kg}^{-1}\right)=0.033(\%$ clay $)+9.154 ; R^{2}=0.007 ; n=29 ; P>0.05$

Similar results were previously obtained for the soil profiles from Aísa and Ordesa (Badía et al., 2002a) and for the Ecomont experimental site of Fragen (Badía and Martí, 1999), all located in the southern Pyrenees. If we consider an intermediate quality of organic matter $(200 \mathrm{cmol} / \mathrm{kg})$ and according to the aforementioned relationships, the CEC of clays range from 10 to $40 \mathrm{cmol}_{(+)} \mathrm{kg}^{-1}$; pointing to mainly illite clays. The fine silt fraction of these soils can also be a source of exchange capacity, easily predominating over the clay fraction (Wilson, 2019).

As found in other grasslands, SOC was positively correlated $(\mathrm{p}<0.01)$ with total $\mathrm{N}$ and the content of main nutrients (Badía and Martí, 1999; Cao et al., 2013). In a previous study, Armas et al. (2020), comparing the same soil depth $(0-5 \mathrm{~cm})$, found significant differences $(\mathrm{p}<0.05)$ in $\mathrm{C} / \mathrm{N}$ ratio, higher in $\mathrm{L} 1$ (13.0) than in L2 (10.8). Additionally, Pintaldi et al. (2016) found that the $\mathrm{C} / \mathrm{N}$ ratio in the topsoil $(0-10 \mathrm{~cm})$ of Nardus stricta hummocks had a significantly greater value than that in the interhummocks (13.8 versus 12.9) in the Alps; they found a higher content of $\mathrm{N}^{-\mathrm{NO}_{3}}{ }^{-}$in the soils of interhummocks than in hummocks. In both locations (Pyrenees and Alps), this fact was related to differences in grassland species composition, which contributed to the different qualities of the organic matter. In fact, Pintaldi et al. (2016) verified a faster decomposition of forbs in nutrient-rich interhummock topsoils compared to that of podzolized hummock positions and an overall slower decomposition rate for Nardus litter.

Fig. 5. Variation with depth of $\delta^{13} \mathrm{C}, \delta^{15} \mathrm{~N}$ and the $\delta^{13} \mathrm{C} / \delta^{15} \mathrm{~N}$ ratio ratio in soil profiles of L1 and L2 cumulative levels.

Again, taking the set of values of the horizons of each profile, the isotope composition $\left(\delta^{13} \mathrm{C}, \delta^{15} \mathrm{~N}\right.$ and the $\delta^{13} \mathrm{C} / \delta^{15} \mathrm{~N}$ ratio) is lighter in L2 soils than in L1 soils (Table 1). Isotopic enrichment is observed with depth for both soils (Fig. 5). It is known that $\mathrm{SOC}$ is progressively ${ }^{13} \mathrm{C}$ enriched during decomposition and that $\delta^{13} \mathrm{C}$ values 
usually increase with soil depth (Zech et al., 1997; Brunn et al., 2014). Therefore, the observed $\delta{ }^{13} \mathrm{C}$ enriched values with depth, both in L1 and L2 soils, may be an evidence of further evolution of the organic matter. For $\mathrm{L} 1 \delta^{13} \mathrm{C}$ values remain fairly constant with depth $(10-80 \mathrm{~cm})$ and only a substantial $\mathrm{C}$ enrichment is observed at depths below $80 \mathrm{~cm}$, probably this is due to the influence of the presence of particularly isotopically enriched inorganic $\mathrm{C}$ from the parent rock carbonates (Appendix 4).

Lower $\delta^{15} \mathrm{~N}$ vales were found in $\mathrm{L} 2$ than in $\mathrm{L} 1$, which can be related to changes in plant species composition (Pardo and Nadelhoffer, 2010). In fact, this is in good agreement with the presence of a higher proportion and variety of nitrogen fixing species (Fabaceae) in the L2 soil, such as: Anthyllis vulneraria L., Lotus corniculatus L., Medicago suffruticosa Ramond ex DC., Oxytropis neglecta Ten., Trifolium montanum L., T. pratense L., and T. repens L. (Armas et al., 2020), adding ${ }^{15} \mathrm{~N}$ depleted biomass to L2 soils. Also $\delta^{15} \mathrm{~N}$ enrichments at soil depth are attributed to the strong isotopic fractionation that occurs during ammonification, nitrification and denitrification processes, resulting in $\delta^{15} \mathrm{~N}$ depleted ions $\left(\mathrm{NH}_{4}{ }^{+}, \mathrm{NO}_{3}{ }^{-}\right.$and $\left.\mathrm{N}_{2} \mathrm{O}\right)$ and the consequent $\mathrm{N}^{15}$ enriched residue (Makarov, 2009); this may explain the $\delta^{15} \mathrm{~N}$ enrichment observed with soil depth. Similarly, Pintaldi et al (2016) found a higher content of mineral $\mathrm{N}$ in cryoturbed soils of interhummocks than that in Nardus-hummocks in subalpine grassland of the Alps. Also bioturbation processes (by wild boards, moles, ants, etc) increase the mineralization of the organic matter and $\mathrm{N}$ availability. For instance, wild board tuning over the soil looking for underground feeding resources, increases $\mathrm{NO}_{3}{ }^{-} \mathrm{N}$ availability and phosphorous (Bueno et al., 2013). Also, yellow meadow ant (Lasius flavus) mound building activity alters the physico-chemical properties of grassland soils. Specifically, a depletion of readily soluble and labile organic matter and an increase in $\mathrm{EC}, \mathrm{pH}$ and base cations has been found in the ant mounds, at $0-5 \mathrm{~cm}$ soil depth (Ehrle et al., 2019). These authors note that these effects are more pronounced in some soils, ie: Haplic Stagnosol and an Umbric Leptosol, than in others, ie: Stagnic Luvisol and Stagnic Leptosol, which relates to the stronger contrast between topsoil and subsoil organic matter content in the former soils. Additionally, in a previous work they found that the ant mound development stages (young, middle-aged and fully developed), this mean the time factor is an important predictor of the nutritional status of a mound (Ehrle et al., 2017). It should be considered that the time factor for mound construction can be a few years, but for the cumulative levels of this study could be approximately thousands (L1) or hundreds (L2) of years. 


\subsubsection{Physical properties}

L1 and L2 soils share many physical properties; both have high structural stability and porosity, especially in topsoil horizons. They also share a fine texture, very homogeneous throughout the profiles, that is mainly silty clay or silty clay loam (Fig. 6). By contrast, the amount of coarse elements $(>2 \mathrm{~mm})$ was significantly $(\mathrm{t}=2.39, \mathrm{p}=$ $0.037)$ lower in $\mathrm{L} 1(1.8 \%, \mathrm{SD}=2.8)$ than in $\mathrm{L} 2(8.3 \%, \mathrm{SD}=9.9)$, considering the set of horizons of each profile (Appendix 5). Stones are mainly gravel-sized and calcareous (limestones or marlstones), which can be a source of calcium by calcite dissolution. Their flat-angular shapes evidence proximity to the source area: higher areas of the hillside that suffer strong erosive processes.

The main difference in physical properties is related to the thickness of the soil profile, which is always greater than $50 \mathrm{~cm}$ in L1 and less in L2. Due to these differences in effective profile thickness, the WHC ranges from moderate to very high in L1 (always higher than $150 \mathrm{~mm} /$ profile) and from low to very low in L2 (always lower than $100 \mathrm{~mm} /$ profile). The parameters related to water retention (FC, PWP) are greater in the topsoil horizons of both sites due to their high organic matter content and the aforementioned textural homogeneity with depth (Appendix 6).

Fig. 6. Textural classes for soil horizons analyzed within the USDA-SCS soil textural triangle; in blue, horizons $(n=29)$ belonging to L1 soils and in red, horizons $(n=17)$ belonging to L2 soils.

SAS is very high (>90\%) in both the L1 and the L2 soils up to $40 \mathrm{~cm}$ depth, at which it decreases (Appendix 7). MWD, which is very fine in the topsoil, increases with soil depth. Both MWD and SAS were significantly $(\mathrm{p}<0.01)$ correlated with SOC, with the first positively $(\mathrm{R}=0.77)$ and the second negatively $(\mathrm{R}=-0.83)$. It is well known that SOC enhances aggregation through the bonding of primary soil particles as well as cations (Bronick and Lal, 2005). The porosity, also related to the aforementioned parameters, has similar ranges for the L1 soil and the L2 soil $(65.5<\%$, v/v <48.6).

The relationships between soil properties can be visualized in the PCA, where, moreover, we have a synthetic view of the samples of all horizons of the L1 and L2 soils (Fig. 8). The first two components of the PCA explained $66.6 \%$ of the total 
variance observed. The first component represents a gradient related to SOC and related properties, that is, surface horizons in relation to subsurface horizons. The second axis shows a gradient related to soil reaction and divides the samples of the acid L1 soils from L2 samples. Some subsurface horizons of L1 are similar to L2 horizons, which could indicate that the dismantling of soil/level L1 gives rise to L2 (Fig. 7).

Fig. 7. Principal Component Analysis (PCA): diagram of the factorial loads in the first two axes of the soil properties (left graph) and the horizons (right graph) of L1 and L2 soils. For left graph, soil properties abbreviations have already been indicated in the text. For right graph, in the horizons of the L1 (N, Nardion) and L2 (B, Bromion) profiles (1, 2 and 4), the letters indicate the most superficial (a) to the deepest horizons $(b, c \ldots f)$.

\subsection{Soil formation and classification}

Soil forming processes in La Estiva include weathering and accumulation of organic matter. Since the parent material in the study site is mostly calcareous rocks (marls, limestones, marlstones), calcite weathering (carbonation) is the main alteration process. Dissolved carbon dioxide from the activity of microorganisms and roots and, to a lesser extent, from rainwater forms carbonic acid, which dissolves the calcite in rocks and leaves a fine silicate residue. Because precipitation inputs to the soil exceed losses by evapotranspiration in the study site, the solutes move downward, and they are leached from the soil (lixiviation). In fact, carbonates are found in very few profiles and only in deep horizons and in a small amount $(<5 \%)$. The percolating water descends until it comes into contact with the limestones ( $\mathrm{R}$ layer) that, if compact, generate occasional reduction processes in horizon $\mathrm{C}$.

Soil forming processes result in different sequences and diagnostic horizons, mainly Ah-Bw-C-R in L1 and Ah-(Bw)-R in L2. Genetic horizons Ah do not meet the criteria that allow them to be diagnostic horizons. By colour and thickness, they do not become mollic or umbric. However, they seem to evolve with time and geomorphologic stability toward mollic or umbric horizons both in the Alps (Rowley et al, 2020) and in the Pyrenees (Badía et al., 2002b). Specifically, in nearby areas (Cuello Arenas), the current topsoil horizons evolve toward umbric horizons for the L1 soil with Nardus-mat grasslands and toward mollic horizons for the L2 soil with chalk-grasslands (Badía et al., 2002b). 
The genetic $\mathrm{Bw}$ horizons with a silty clay or silty clay loam texture, strong subangular structure, absence of carbonates and thickness greater than $15 \mathrm{~cm}$ fulfil the requirements of the cambic diagnostic horizon. The presence of this horizon, as well as soil depth, has a strong influence on soil classification. According to WRB system (IUSS, 205), L1 soils have a cambic horizon and continuous rock at depth, although variable and usually greater than $100 \mathrm{~cm}$ from the soil surface. Since the BS is greater than $50 \%$ between 20 and $100 \mathrm{~cm}$ from the soil surface, soils on L1 are usually classified as Orthoeutric Cambisol. In this case, Clayic and Humic are the most common supplementary qualifiers (Fig. 8). If the leaching of basic cations continues over time, under conditions of geomorphological stability, this soil evolves toward Dystric Cambisol and even to Cambic Umbrisol in the vicinity (Badía et al., 2002b); these types of soils fit with the low nutritional requirements of tussock grass (Nardus stricta) it supports (Korner, 2003). Instead, soils on L2 have continuous rock within 25 $\mathrm{cm}$ of the soil surface, which includes them in the group Leptosols; sometimes the L2 soils exceed this thickness but without reaching $50 \mathrm{~cm}$, which with a cambic horizon takes us to a gradation of Cambic Leptosol to Epileptic Cambisol. With a soil reaction close to neutrality and a BS close to $100 \%$ in the whole profile, the qualifier Hypereutric is common to both soil reference groups, and it allows linking a soil property key in the presence of the type of grass it supports (chalk grasslands, which might well be called hypereutric grasslands). The most common supplementary qualifiers are Loamic and Ochric for L2 soils (Fig. 8).

The sediments accumulated after the erosion of L1 can be the new parental material (pedosediments) for soil formation in L2, which can be very recent, ie from the Little Ice Age (LIA, late 17th century to middle 19th century), when a colder and more humid climate would stabilize slopes, as in other European sites (Henkner et al., 2017).

Świtoniak (2014), studying a district in northeastern Poland, found that eroded soils overlap $39.5 \%$ of agricultural area and $2.5 \%$ of forest sites; in the case of completely eroded soils, soil loss exceeds $100 \mathrm{~cm}$. Świtoniak (2014) found that Bt and Ck horizons were exhumed, which had a substantial influence on the properties of new surface horizons, such as texture, content of organic matter, and $\mathrm{pH}$ values. Something similar happens in our soils with some properties, such as $\mathrm{pH}$. 
Fig. 8. Main soils (WRB) in the L1 and L2 cumulative levels under both types of grasslands.

Remarkably, these soils in their evolution over time have a double path: 1) stability that allows them, therefore, to acquire greater development, greater thickness, more genetic horizons, greater washing, etc. and 2) a path of geomorphological instability, which leads them to rejuvenation. As indicated by Huggett (1998), soils "evolve" through continual creation and destruction at all scales and may progress, stay the same, or retrogress depending on the environmental circumstances, such as anthropic activities and climate changes.

As with the WRB, the presence of the cambic horizon and the thickness of the soil are key in the first categories of soil taxonomy classification (USDA). In L1, with a cambic horizon with its upper boundary within $100 \mathrm{~cm}$ of the mineral soil surface (usually at $10 \mathrm{~cm}$ ) and its lower boundary at a depth of $25 \mathrm{~cm}$ or more below the mineral surface (which rarely occurs in L2), the soils belong to Inceptisols. At the suborder level, moisture and temperature regimes are required. Having no direct soil climate data, the approximation is established based on the atmospheric data. Because we assume they have a cryic soil temperature regime, without mollic or umbric horizons and $\mathrm{BS}$ (by $\mathrm{NH}_{4} \mathrm{OAc}$ ) of $50 \%$ or more in the whole profile, they belong to the Great Group of Haplocryepts, subgroup Typic Haplocryept (Appendix 8). For those thicker profiles, values higher than $0.2 \%$ organic carbon (Holocene period) could be found at a soil depth of $125 \mathrm{~cm}$, which would replace the qualifier typic by fluventic, although it is evident that the soil is not associated with fluvial deposits. The accumulation of SOC is promoted by a high $\mathrm{Ca}^{2+}$ availability (Rowley et al., 2018)

In the case of soils in L2, some of them also belong to the Great Group of Haplocryepts, but given the presence of a lithic contact within $50 \mathrm{~cm}$ of the soil surface, to the subgroup Lithic Haplocryept. The cambic horizon (15 cm thick) can be defined even in L2 soils, sometimes with its lower boundary at a depth less than $25 \mathrm{~cm}$ below the mineral soil surface, but because it is combined with a cryic temperature regime, it belongs to the Great Group of Haplocryepts, although in this case, to the subgroup of Lithic Haplocryepts. The correspondence of Leptosols (WRB) with Entisols (ST) would seem logical, but in this case, the coincidence of the cambic horizon (with its upper limit at $5 \mathrm{~cm}$ of the mineral surface and its lower boundary at a depth of approximately 
20 or $25 \mathrm{~cm}$ ) with the cryic regime makes some Leptosols belong to the Inceptisols. Only soils with extreme thinness belong to the Lithic Cryorthent (Fig. 9).

At the family level, calcareous and reaction classes are used for Entisols but not for Inceptisols. In any case, all profiles are non-calcareous in all parts of the control section and have a $\mathrm{pH}\left(\mathrm{H}_{2} \mathrm{O}\right)$ higher than 5.5 in some or all horizons in the control section (nonacid class, applied to Entisols). In this property, large differences between both classifications are observed due to the lack of detail in ST for the soil reaction or the BS. Although previous versions of the ST differentiate two subgroups (Eutrocryepts and Dystrocryepts), the current version is wider with four subgroups: Humicryepts, Calcicryepts, Dystrocyepts and Haplocryepts. The cryptic use of the prefix "haplo" and the non-application of a reaction class in the Inceptisols could be considered a deficit with respect to the denomination by WRB, especially for the relationship that this property has with the vegetation cover it supports. Both the Cryepts and the Cryorthents, with whom it is associated, each supposes $1 \%$ of the surface of Spain (Gómez-Miguel and Badía, 2016). The short formation time of these soils, although under a climate favourable to evolution, fits them in Entisols and Inceptisols; next, the use of climate, or more precisely moisture and temperature regimes, acquires great importance in its classification. Some authors consider that climate is overvalued in relation to the other soil-forming factors in defining taxa in soil taxonomy (Bockheim et al., 2014; Wilson, 2019).

\section{Conclusions}

The results confirm that two cumulative levels (L1 and L2) support soils with contrasting properties that give shelter to grasslands of different floristic composition and pastoral value: Nardus-mat grasslands (in L1) or chalk grasslands (in L2). The rejuvenation of the higher cumulative level L1 by gully erosion, due to the inconstancy of environmental conditions, either for climatic changes or for anthropic activities, results in a lower level, L2. The greater stability and, therefore, the time of soil formation in L1 explains the differences in respect to L2.

Soils in L1 have a significantly lower $\mathrm{pH}$, a lower base saturation, and lower available $\mathrm{Ca}^{2+}$ content than those in $\mathrm{L} 2$, reflecting a more intense leaching process, consistent with a longer period of formation. At both levels, the soils practically lack 
carbonates, even though limestones and marls are the parental material. The isotope composition $\left(\delta^{13} \mathrm{C}, \delta^{15} \mathrm{~N}\right.$ and the $\delta^{13} \mathrm{C} / \delta^{15} \mathrm{~N}$ ratio) is lighter in $\mathrm{L} 2$ soils than in L1, due to the higher proportion of legumes in L2 soils than in L1. In both levels, evident $\mathrm{C}$ and $\mathrm{N}$ isotope composition enrichments with depth were observed and related to organic matter decomposition. Moreover, the occasional presence of traces of carbonates at the base of L1 soil is also related to its significant $\delta^{13} \mathrm{C}$ enrichment. Unlike the chemical properties, physical properties were similar between L1 and L2 soils: very low rock fragment content, high soil aggregate stability and a silty clay or silty clay loam textural class, with a homogeneous particle-size distribution with depth. Instead, the soils in L1 have a greater thickness and, thus, a higher water-holding capacity than those in L2. In any case, both the soil profiles in L1 and L2 levels are little evolved, evidencing their youth (a small number of centuries and thousands of years, respectively).

Concerning the mentioned properties and processes, two main reference soil groups (WRB) are defined: Cambisols (L1) and Leptosols (L2). So, over L1 the main soil is classified as Orthoeutric Cambisols (Clayic, Humic), with Nardus matgrasslands, and the soil over L2 as Hypereutric Leptosols (Loamic, Ochric), with chalkgrasslands; in the latter case, hypereutric grasslands would be a more accurate name. The Soil Taxonomy System (USDA), because of the use of the temperature regime, classifies both soils as Haplocryept, at the level of Great Group, separating them at the subgroup level as Typic Haplocryept (L1) and Lithic Haplocryept (L2), according to the depth at which limestone appears (lithic contact).

Definitely, the geomorphologic context is linked to the pedodiversity, which goes hand in hand with plant diversity in this subalpine environment.

\section{Acknowledgments}

This study is part of the results of a microproject funded by the "Instituto de Estudios Altoaragoneses-Diputación de Huesca (Call 2018). Lucía Buendía was supported by a novel research contract, funded by the Institute of Research into Environmental Sciences (IUCA) of the University of Zaragoza. This work has been partially financed by the Regional Government of Aragón (Geoforest research group S51_17R) cofinanced with FEDER 2014-2020 "Construyendo Europa desde Aragon". The authors would also like to thank Federico Fillat for his help in the field and for their 
constructive comments and suggestions, which led to a substantial improvement of the paper.

\section{References}

Alonso, I., García-Olalla, C., 1997. Mineral composition of soils and vegetation from six mountain grassland communities in northern Spain. Journal of the Science of Food and Agriculture 73(2), 200-206.

Armas Herrera, C.M., Pérez Lambán, F., Badía Villas, D., Peña Monné, J.L., González Pérez, J.A., Picazo, J.V., Jiménez Morillo, N.T., Sampietro Vattuone, M.M., Alcolea Gracia, M., 2019. Pyrogenic organic matter from paleo-fires during the Holocene: A case study in a sequence of buried soils at the Central Ebro Basin (NE-Spain). J. of Envir. Manag. 241, 558 - 566. https://doi.org/10.1016/j.jenvman.2018.09.104

Armas-Herrera, C.M., Badía-Villas, D., Mora, JL., Gómez, D., 2020. Plant-topsoil relationships underlying subalpine patchiness. Science of Total Environment 712, 134483. DOI: https://doi.org/10.1016/j.scitotenv.2019.134483.

Badía, D., Martí, C. (eds.), 1999. Suelos del Pirineo Central: Fragen. 190 pp. ISBN 84605-8942-0.

Badía, D. Lalueza, B., Vadillo, L., Martí, C., García-González, R., 2002a. Caracterización edáfica de cinco comunidades pascícolas en los puertos de Aisa y Ordesa (Pirineo Central): In: Chocarro, C, Santiveri, F., Fanlo, R., Bovet, I., Lloveras, J. Eds. Producción de pastos, forrajes y céspedes. Lleida, Spain.

Badía, D., García-González, R. Martí, C., 2002b. Clasificación de suelos en pastos alpinos de Aísa y Ordesa (Pirineo Central). Edafología 9, 11-22.

Badía, D., Martí, C., Sánchez, J.R., Fillat, F.; Aguirre, J., Gómez, D., 2008a. Influence of livestock soil eutrophication on floral composition in the Pyrenees Mountains. Journal of Mountain Science 5, 63-72. DOI: 10.1007/s11629-008-0063-6.

Badía, D., Fillat, F., Martí, C., Aguirre, J., Gómez, D., Sánchez, J.R., 2008b. Soil chemistry in long-term livestock camping areas in Pyrenean summer pastures. Agrochimica 52 (3), 189-199.

Badía, D., Marti, C., Aznar, J.M., León, J., 2013. Influence of slope and parent rock on soil genesis and classification in semiarid mountainous environments. Catena 193, $13-21$.

Bitterlich, W., Badía, D., Martí, C., De Siena, C., 1999. Physical and chemical soil properties, pp. 109-111. In: Land-Use Changes in European Mountain ecosystems. 
Ecomont: Concepts and results. Cernusca, A., Tappeiner, U.; Bayfield, N. eds.. Blackwell Science Ltd. Berlin.

Bal, M.C., Allée, P. Liard, M., 2015. The origins of a Nardus stricta grassland through soil charcoal analyses: Reconstructing the history of a mountain cultural landscape (Mont Lozère, France) since the Neolithic. Quaternary International 366, 3-14.

Birkeland, P.W., 1999. Soils and geomorphology, $3^{\text {rd }}$ ed. New York. Oxford University Press. pp. 430.

Benito Alonso, J.L. 2006. Vegetación del Parque Nacional de Ordesa y Monte Perdido (Sobrarbe, Pirineo central aragonés). Publicaciones del Consejo de Protección de la Naturaleza de Aragón; Serie Investigación. Zaragoza, pp. 425 ISBN 84-89862-54-0.

Bockheim, J.G., Gennadiyev, A.N. Hartemink, A.E., Brevik, E.C., 2014. Soil-forming factors and Soil Taxonomy. Geoderma 226-227, 231-237.

Bogner, C., Borken, W., Huwe, B., 2012. Impact of preferential flow on soil chemistry of a podzol. Geoderma 175-176, 37-46. DOI:10.1016/j.geoderma.2012.01.019.

Bojko, O., Kabala, C., 2017. Organic carbon pools in mountain soils-Sources of variability and predicted changes in relation to climate and land use changes. Catena 149, 209-220.

Braun-Blanquet, J., 1948. La végétation alpine des Pyrénées orientales. Étude de phytosociologie comparée. Monografía de la estación de Estudios Pirenaicos y del Instituto español de edafologia, ecologia y fisiologia vegetal, Barcelone, $306 \mathrm{p}$.

Bremner J.M., Mulvaney C.S., 1982. Nitrogen total, In: Page AL Miller RH, Keeney DR (eds.), Methods of Soil Analysis. pp. 595-624. Part 2: Chemical and Microbiological Properties, 2nd edition. American Society of Agronomy, Madison, Wisconsin.

Bronick, C.J., Lal R., 2005. Soil structure and management: a review. Geoderma 124,322. DOI:10.1016/j.geoderma.2004.03.005.

Brunn, M., Spielvogel, S., Sauer, T., Oelmann, Y., 2014. Temperature and precipitation effects on $\delta 13 \mathrm{C}$ depth profiles in SOM under temperate beech forests. Geoderma 235-236, 146-153. http://dx.doi.org/10.1016/j.geoderma.2014.07.007.

Bueno, A., Azorín, J., Gómez, D., Alados, C., Badía, D., 2013. Occurrence and intenity of wild board disturbances, effects on the physical and chemical soil properties. Plant Soil 373, 243-256. 
Cao, Y.Z., Wang, X.D., Lu, X.Y., Yan, Y., Fan, J. 2013. Soil Organic Carbon and Nutrients along an Alpine Grassland Transect across Northern Tibet. Journal of Mountain Science 10(4), 564-573. DOI: 10.1007/s11629-012-2431-5

Clemente Conte, I., Rey Lanaspa, J., Gassiot Ballbè, E. Obea Gómez,L. Díaz Bonilla, S. Quesada Carrasco, M., Rodríguez Antón, D., Sánchez Bonastre, X. García Casas, D. Salvador Baiges, G., Mazzucco, N. Viñerta, A. García Díaz, V., 2017. La cueva de Coro Trasito (Tella-Sin) uno de los primeros asentamientos pastoriles en la periferia del PNOMP. III Jornada de Investigación del PNOMP. Huesca.

Ehrle, A. Andersen, A.N., Levick, S.R., Schumacher, J. Trumbore, S.E., Michalzik, B. 2017. Yellow-meadow ant (Lasius flavus) mound development determines soil properties and growth responses of different plant functional types. European Journal of Soil Biology 81, 83-93.

Ehrle, A. Potthast, K., Tischer, A., E. Trumbore, S.E., Michalzik, B. 2019. Soil properties determine how Lasius flavus impact on topsoil organic matter and nutrient distribution in central Germany. Applied Soil Ecology 133, 166-176. https://doi.org/10.1016/j.apsoil.2018.08.021

FAO, 2006. Guidelines for soil description. 97 pp. Rome, Italy.

Fillat, F., García-González, R., Gómez, D., Reiné, R., 2008. Pastos del Pirineo. Madrid: Consejo Superior de Investigaciones Científicas. 319 pp. Madrid. Spain.

Fillat, F., Chocarro, C., Fanlo, R., Pardo, F., Martí, C., Gómez, A., Alvera, B. 1999. Results from the Pyreneean site on history, soil characteristics and vegetation distribution, pp. 289-304. In:_Land-use changes in European mountain Ecosystems. Eds. Cernusca, A., Tappeiner, U., Bayfield, N. Blackwell Science Ltd. Berlin.

Ford, D.J., Cookson, W.R., Adams, M.A., Grierson, P.F., 2007. Role of soil drying in nitrogen mineralization and microbial community function in semi-arid grasslands of north- west Australia. Soil Biol. Biochem. 39, 1557-1569.

García-González, R., Gómez-García, D. 2014. Cambios del valor eco-pastoral tras ausencia de pastoreo en pastos de Bromion y Nardion del Pirineo central. 53 Reunión Científica de la SEEP "Pastos y PAC": 25-32. ISBN: 978-84-697-0561-2

García-Ruiz, J.M.; M. Arbella, M., 1981. Modelos de erosión en el piso subalpino: la degradación de los loess del Macizo de Monte Perdido (Pirineo central español). Pirineos 114, 35-58.

García-Ruiz, J.M. \& Puigdefábregas, J., 1982. Formas de erosión en el flysch eoceno surpirenaico. Cuadernos de investigación Geográfica 8, 85-128. 
García-Ruiz, J.M., Palacios, D., De Andrés, N., Valero-Garcés, B.L., López-Moreno, J.I., Sanjuán, Y. 2014. Holocene and 'Little Ice Age' glacial activity in the Marboré Cirque, Monte Perdido Massif, Central Spanish Pyrenees. The Holocene 24, 14391452. doi: $10.1177 / 0959683614544053$.

Gassiot Ballbè, A., Clemente Conte, I,. Mazzucco, N., García-Casas D., Laura ObeaGómez, David Rodríguez-Antón, D. (2016). Surface surveying in high mountain areas, is it possible? Some methodological considerations. Quaternary International, 402, 35-45.

Gee G.W., Bauder J.W., 1986. Particle-size analysis. In: Klute A (Eds.), Methods of soil analysis. pp 383-412. Part 1: Physical and mineralogical methods, 2nd edition, American Society of Agronomy. Madison, Wisconsin, USA..

Girona-García. A., Badía-Villas. D., Jiménez-Morillo, N.T., De la Rosa, J.M. GonzálezPérez, J.A., 2018. Soil C and $\mathrm{N}$ isotope composition after a centennial Scots pine afforestation in podzols of native European beech forests in NE-Spain. Catena 165, 434-441.

Gómez, D. 2008. Pastos del Pirineo: Breve Descripción Ecológica y Florística. In: Fillat et al. (eds) Pastos del Pirineo. CSIC-Diputación de Huesca, Madrid, España, pp. 111-140.

Gómez-Miguel V.D., Badía D., 2016. Soil distribution and classification. In: The Soils of Spain, Gallardo JF. Springer, Berlin, Germany. ISBN 978-3-319-20541-0.

González, C., Ortigosa, L, Martí, C., García-Ruiz, J.M. 1995. The study of the spatial organization of geomorphic processes in mountain areas using GIS. Mountain Research and Development15, 241-249. https://doi.org/10.2307/3673931.

González-Sampériz, P.; Aranbarri, J.; Pérez-Sanz, A.; Gil-Romera, G.; Moreno, A.; Leunda, M.;Sevilla-Callejo, M.; Corella, J. P.; Morellón, M.; Oliva, B., y ValeroGarcés, B., 2017. Environmental and climate change in the southern Central Pyrenees since the Last Glacial Maximum: A view from the lake records. Catena 149, 668-688. doi: 10.1016/j.catena.2016.07.041

González-Sampériz, P., L. Montes, J. Aranbarri, M. Leunda, R. Domingo, R. Laborda, Y. Sanjuán, G. Gil-Romera, T. Lasanta, García-Ruiz, J.M., 2019. Escenarios, Tiempo e Indicadores Paleoambientales para la Identificación del Antropoceno. In: El Paisaje Vegetal del Pirineo Central (NE-Iberia) Geographical Research Letters 45, 167-193. 
Grab, S.W., 1997. Thermal regime for a thufa apex and its adjoining depression, Mashai Valley. Lesotho. Permafrost Periglac. Process. 8, 437-445.

Henkner, J., Ahlrichs, J.J., Downey, S., Fuchs, M., James, B.R., Knopf, T., Scholten, T., Teuber, S., Kühn, P. (2017). Archaeopedology and chronostratigraphy of colluvial deposits as a proxy for regional land use history (Baar, southwest Germany) . Catena 155, 93-113. http://dx.doi.org/10.1016/j.catena.2017.03.005

Huggett, R.J., 1998. Soil chronosequences, soil development, and soil evolution: a critical review. Catena 32, 155-172.

IUSS Working group WRB, 2015. World reference base for soil resources 2014, update 2015. International soil classification system for naming soils and creating legends for soil maps. World Soil Resources Reports 106. FAO, Rome, Italy.

Klute, A., 1986. Methods of soil analysis. Part 1. Physical and mineralogical methods. 2on. ed. A.S.A. - S.S.S.A. Madison, Wisconsin.

Körner, C., 2003. Alpine plant life, 2nd edn. Springer-Verlag, Berlin.

Kowalska, J.B., Zaleski, T., Józefowska, A., Mazurek , R., 2019. Soil formation on calcium carbonate-rich parent material in the outer Carpathian Mountains - A case study. Catena 174, 436-451. https://doi.org/10.1016/j.catena.2018.11.025

Laborda, R., Villalba-Mouco, V., Lanau, P., Gisbert, M., Sebastián, M., Domingo, R., Montes, L., 2017. El Puerto Bajo de Góriz (Parque Nacional de Ordesa y Monte Perdido): Ocupación y explotación de un paisaje de alta montaña desde la prehistoria hasta el siglo xx. Bolskan 26, 9-30.

Leunda, M., González-Sampériz, P., Gil-Romera, G., Aranbarri J., Morena, A., OlivaUrcia B., Sevilla Callejo M., Valero-Garcés, B., 2017. The Late-Glacial and Holocene Marboré Lake sequence (2612 m a.s.1., Central Pyrenees, Spain): Testing high altitude sites sensitivity to millennial scale vegetation and climate variability, Global and Planetary Change 157, 214-231. https://doi.org/10.1016/j.gloplacha.2017.08.008

Leunda, M., Gil-Romera, G., Daniau, A.L., Benito, B.M., González-Sampériz, P., 2020. Holocene fire and vegetation dynamics in the Central Pyrenees (Spain). Catena 188, 104411 https://doi.org/10.1016/j.catena.2019.104411

Löbmann, M.T., Tonin, R., Wellstein, C., Zerbe, S., 2020. Determination of the surfacemat effect of grassland slopes as a measure for shallow slope stability. Catena, 187: 104397 https://doi.org/10.1016/j.catena.2019.104397 
Makarov, M.I., 2009. The nitrogen isotopic composition in soils and plants: its use in environmental studies: a review. Eurasian Soil Sci. 42, 1335-1347. http://dx.doi. org/10.1134/S1064229309120035.

Montserrat Martí, J., 1992. Evolución glaciar y post-glaciar del clima y la vegetación en la vertiente sur del Pirineo: Estudio palinológico. Monografías del IPE, $\mathrm{n}^{\circ} 6$. Zaragoza.

Nelson R.E. 1982. Carbonate and gypsum. In: A.L. Page, R.H. Miller and D.R. Keeney (Eds.), Methods of soil analysis. Part 2: Chemical and microbiological properties, pages 181-198. American Society of Agronomy. Madison, Wisconsin. USA.

Nelson R.E., Sommers, L.E., 1982. Total carbon and organic matter. In: A.L. Page, R.H. Miller and D.R. Keeney (Eds.), Methods of soil analysis. Part 2: Chemical and microbiological properties, pages 539-557. American Society of Agronomy. Madison, Wisconsin. USA.

Orbán, I. Birks, H., Vincze, I., Finsinger, W., Pál, I., Marinova, E: Jakab, G., Braun, M. Hubay, K. Bíró, T. Magyari, E.K. 2018. Treeline and timberline dynamics on the northern and southern slopes of the Retezat Mountains (Romania) during the late glacial and the Holocene. Quaternary International 477, 59-78.

Otal, C., Badía, D., Fillat, F., 2005. Génesis y clasificación de una catena de suelos en pastos subalpinos del Pirineo Central. Georgica 11, 67-78.

Pardo, L.H., Nadelhoffer, K.J., 2010. Using nitrogen isotope ratios to assess terrestrial ecosystems at Regional and Global Scales. In: West, J.B., Bowen, G.J., Dawson, T.E., Tu, K.P. (Eds.), Isoscapes: Understanding Movement, Pattern, and Process on Earth Through Isotope Mapping. Springer, The Netherlands.

Peña Monné, J.L.,1997. Cartografía geomorfológica básica y aplicada. Ed. Geoforma. Logroño.

Peña Monné, J.L., 2018. Geoarqueología aplicada a la reconstrucción paleoambiental: La evolución del Holoceno superior en el NE de España. Boletín Geológico y Minero, 129 (1/2), 285-303. http://doi.org/10.21701/bolgeomin.129.1.011

Pérez-Lambán, F., Peña-Monné, J.L., Fanlo, J., Picazo, J.V., Badia, D., Rubio, V., García-Jiménez, R., Sampietro, M.M., 2014. Paleoenvironmental and geoarchaeological reconstruction from late Holocene slope records (Lower Huerva Valley, Ebro Basin, NE Spain). Quaternary Research 81, 1-14. http://dx.doi.org/10.1016/j.yqres.2013.10.011 
Pintaldi, E., D'Amico, M.E., Siniscalco, C., Cremonese, E. Celi, L., Filippa, G., Prati, M. Freppaz, M., 2016. Hummocks affect soil properties and soil-vegetation relationships in a subalpine grassland (North-Western Italian Alps). Catena 145, 214226.

Rhoades J.D., 1982a. Soluble salts. In: Page AL, Miller RH, Keeney DR (Eds.), Methods of soil analysis. Part 2: Chemical and microbiological properties, pages 167-179. American Society of Agronomy. Madison, Wisconsin. USA.

Rhoades J.D., 1982b. Cation exchange capacity. In: Page AL, Miller RH, Keeney DR (Eds.), Methods of soil analysis. Part 2: Chemical and microbiological properties, pages 149-157. American Society of Agronomy. Madison, Wisconsin. USA.

Ríos Aragüés, L.M., Lanaja, J.M., Frutos, E., 1982. Mapa Geológico de España 1:50.000 serie MAGNA, hoja 178 (Broto). Madrid, I.G.M.E.

Rowley, M.C., Grand, S., Verrecchia, É.P., 2018. Calcium-mediated stabilisation of soil organic carbon. Biogeochemistry 137 (1), 27-49.

Rowley, M.C., Grand, S., Adatte, T., Verrecchia, É.P., 2020. A cascading influence of calcium carbonate on the biogeochemistry and $\mathrm{T}$ pedogenic trajectories of subalpine soils, Switzerland. Geoderma 361, 114065

Samsó Escolà, J. M., Robador Moreno, A., 2018. Mapa geológico del Parque Nacional de Ordesa y Monte Perdido: Escala 1:25.000 IGME. Madrid.

San Miguel, A., 2001. Pastos naturales españoles: caracterización, aprovechamiento y posibilidades de mejora. Fundación Conde del Valle del Salazar. Ediciones Mundiprensa, Madrid.

Serrano-Notivoli, R. Buisán-Sanz, S.T., Abad-Pérez, L.M., Sierra-Álvarez, E., Rodríguez-Ballesteros, C. López-Moreno, J.I., Cuadrat, JM. 2018. Tendencias recientes en precipitación, temperatura y nieve de alta montaña en los Pirineos (Refugio de Góriz, Huesca), pp. 267-280. In: El clima: aire, agua, tierra y fuego. Asociación Española de Climatología y Ministerio para la Transición EcológicaAgencia Estatal de Meteorología, 1060 pages. Madrid.

Soil Survey Staff, 2014. Keys to Soil Taxonomy, 12th ed. USDA-Natural Resources Conservation Service, Washington DC, USA.

Świtoniak, M., 2014. Use of soil profile truncation to estimate influence of accelerated erosion on soil cover transformation in young morainic landscapes, North-Eastern Poland. Catena 116, 173-184. 
Wilcox, R., 2012. Chapter 9 - Correlation and Tests of Independence. En R. B. T.-I. to R. E. and H. T. (Third E. Wilcox (Ed.), Statistical Modeling and Decision Science (pp. 441-469). https://doi.org/https://doi.org/10.1016/B978-0-12-386983-8.00009-3

Wilson, M.J. 2019. The importance of parent material in soil classification: A review in ahistorical context. Catena 182,104-131.

Zech, W., Guggenberger, G., Zalba, P., Peinemann, N., 1997. Soil organic matter transformation in Argentinian Hapludolls. J. Plant Nutr. Soil Sci. 160, 563-571. http://dx.doi.org/10.1002/jpln.19971600507. 
Table 1.

Chemical properties significantly different among L1 and L2 soils, considering the set of horizons by profile $($ Mean $\pm \mathrm{SD})$.

\begin{tabular}{l|c|c|l|l}
\hline & \multicolumn{2}{|c|}{ Soil profile in } & & \\
\hline Soil property & L1 & L2 & P value & Test \\
\hline $\mathrm{pH}\left(\mathrm{H}_{2} \mathrm{O}\right) 1: 2.5$ & $6.0 \pm 0.4$ & $7.1 \pm 0.2$ & $<0.001$ & $\mathrm{t}$ \\
\hline $\mathrm{pH}(\mathrm{KCl}) 1: 2.5$ & $4.1 \pm 0.2$ & $5.7 \pm 0.2$ & $<0.001$ & $\mathrm{t}$ \\
\hline $\mathrm{Al}^{3+}+\mathrm{H}^{+}\left(\mathrm{cmol}_{(+)} / \mathrm{kg}\right)$ & $1.1 \pm 0.6$ & $0.02 \pm 0.02$ & $<0.001$ & $\mathrm{t}$ \\
\hline $\mathrm{EC} 1: 5(\mu \mathrm{S} / \mathrm{cm})$ & $29 \pm 7$ & $73 \pm 10$ & $<0.001$ & $\mathrm{t}$ \\
\hline Exc. $\mathrm{Ca}^{2+}\left(\mathrm{cmol}{ }_{(+)} / \mathrm{kg}\right)$ & $8.5 \pm 1$ & $13.8 \pm 2$ & $<0.001$ & Mann-Whitney U \\
\hline Base Saturation $\left.(\%)_{\delta^{13} \mathrm{C}(\%)}\right)$ & $65 \pm 7$ & $92 \pm 5$ & $<0.001$ & Mann-Whitney U \\
\hline$\delta^{15} \mathrm{~N}(\%)$ & $-24.76 \pm 1.34$ & $-25.93 \pm 0.66$ & $=0.002$ & Mann-Whitney U \\
\hline$\delta^{13} \mathrm{C} / \delta^{15} \mathrm{~N}$ ratio & $9.47 \pm 1.94$ & $6.52 \pm 1.76$ & $<0.001$ & Mann-Whitney U \\
\hline
\end{tabular}




\section{Declaration of interests}

$X$ The authors declare that they have no known competing financial

interests or personal relationships that could have appeared to influence the work reported in this paper.

$\square$ The authors declare the following financial interests/personal relationships, which may be considered as potential competing interests: 
Graphical abstract

Highlights

1. Cumulative levels ( $L 1$ and $L 2)$, with different age, allow the formation of soils with contrasted properties

2. L1 soil, with Nardus-mat grasslands, is more acidic than L2 soil, with chalk grasslands

3. The $\delta^{15} \mathrm{~N}$ is lighter in L2 soil than in L1 soil, due to higher legume proportion in grasslands

4. The erosion of the Orthoeutric Cambisol (in L1) leads to the Hypereutric Leptosol formation (in L2) 